UDC 661.185

\title{
SYNTHESIS AND STUDY INTO COLLOID-CHEMICAL PROPERTIES OF SURFACTANTS ON THE BASIS OF PALM OIL AND ETHANOLAMINES
}

\author{
I.T.Ismayilov \\ Acad. Y.H.Mammadaliyev Institute of Petrochemical Processes \\ National Academy of Sciences of Azerbaijan \\ 30 Khojaly Ave. AZ 1025, Baku, \\ Lomonosov Moscow State University, Faculty of Chemistry, \\ Russia, 119991, Moscow 1, GSP-1, 1-3 Leninskiye Gory \\ e-mail: ismayil999@gmail.com
}

\begin{abstract}
Anionic surfactants $\mathrm{Na}^{+}, \mathrm{K}^{+}, \mathrm{NH}_{4}{ }^{+},-\mathrm{NH}_{2}{ }^{+}-\mathrm{CH}_{2}-\mathrm{CH}_{2}-\mathrm{OH}$ and $-\mathrm{NH}^{+}-\left(\mathrm{CH}_{2}-\mathrm{CH}_{2}-\mathrm{OH}\right)_{2}$ and salts of sulphate-derivatives of higher carboxylic acids have been synthesized. Sulphate-derivatives have been obtained by the interaction of palm oil with ethanolamines (monoethanolamine and diethanolamine) at molar ratio 1:2 followed by modification of the reaction products by sulphuric acid. Basic colloid-chemical properties of synthesized salts and their oil-collecting and oildispersing properties on water surface with different degree of mineralization analyzed.

Keywords: palm oil, ethanolamines, interfacial tension, critical micelle concentration, free adsorption energy
\end{abstract}

\section{Introduction}

Surfactants are most widely used in practically all fields of industry and welfare, too [1, 2]. Application of surfactants can influence on energy state and structure of boundary surface and control the properties of heterogeneous systems through it. Due to its cleansing, moisturizing, dispersing, foaming, and many other properties, they have become the products of choice in many fields of application in oil industry. They are used for drilling, corrosion inhibition of oilfield equipment, dehydration of oil, and added to lubricating oils as additives, etc. Possibility of application of surfactants as corrosion inhibitors have been thoroughly examined on a large scale [4]. Various surfactant mixtures, as well as surfactants of multifunctional purposes are known to be applied in resolving a number of problems through the use of their properties. [3-6]. Hence, selection of a suitable product should be made with due regard for appropriate conditions and product assignment.

Recently, environmental standards conformably to industrial consumption and wider use of new corrosion inhibitors have been applied in industry.

Contemporary hygienic and environ- mental standards provide for replacement of corrosion inhibitors by toxic reagents of the same efficiency with maximum safety for industry and everyday practice. Besides, of great importance is the use of available and inexpensive raw materials for preparation of inhibitors to promote search for new perspective technologies and initial products.

Note that main raw materials for production of surfactants are oil and gas refining products, as well as products of vegetable origin [7-9]. Benefits of vegetable raw materials are, first of all, their renewability and greater ecological safety. Currently, high emphasis is placed on these factors due to the development of "green chemistry". Data given in [10-13], deal with obtaining and analysis of the properties of anionic surfactants synthesized on the basis of triglycerides of some vegetable oils. According to their renewability and ecological acceptability, they may be applied as perspective raw materials for the production of reagents in oil industry.

The paper focuses on the results of obtaining anionic surfactants on the basis of palm oil to comply with their colloid-chemical properties. 


\section{Experimental part}

Sulphate-derivatives of higher carboxylic acids have been synthesized on the basis of palm oil by aminolysis and sulphation.

Palm oil aminolysis has been carried out in the presence of monoethanolamine (MEA) and diethanolamine (DEA) at molar ratio of initial components of palm oil as follows: ethanolamine $=1: 2$.

According to the reaction scheme published in [12], anionic surfactant salts of below-given structures have been obtained by the interaction of bases with sulphatederivatives of higher carboxylic acids:

$\left[\mathrm{R}-\left(\mathrm{CH}_{2} \mathrm{CH}\left(\mathrm{OSO}_{3}-\mathrm{M}\right) \mathrm{CH}_{2}\right)_{\mathrm{n}}-\left(\mathrm{CH}_{2}\right)_{7}-\mathrm{CO}-\mathrm{NH}-\mathrm{CH}_{2}-\mathrm{CH}_{2}-\mathrm{OH}\right]$ and $\left[\mathrm{R}-\left(\mathrm{CH}_{2} \mathrm{CH}\left(\mathrm{OSO}_{3} \mathrm{M}\right) \mathrm{CH}_{2}\right)_{\mathrm{n}}-\left(\mathrm{CH}_{2}\right)_{7}-\mathrm{CO}-\mathrm{N}\left(\mathrm{CH}_{2}-\mathrm{CH}_{2}-\mathrm{OH}\right)_{2}\right]$ $\left(\mathrm{DEA}^{+}\right)$

where $\mathrm{n}=1-3 ; \mathrm{M}-\mathrm{Na}^{+}, \mathrm{K}^{+}, \mathrm{NH}_{4}{ }^{+},-\mathrm{NH}_{2}{ }^{+}-\mathrm{CH}_{2}-\mathrm{CH}_{2}-\mathrm{OH}\left(\mathrm{MЭA}^{+}\right)$и $-\mathrm{NH}^{+}-\left(\mathrm{CH}_{2}-\mathrm{CH}_{2}-\mathrm{OH}\right)_{2}$

The salts are identified as: $\mathrm{PM}_{\mathrm{I}}, \mathrm{PM}_{\mathrm{II}}$, $\mathrm{PM}_{\text {III }}, \mathrm{PM}_{\mathrm{IV}}, \mathrm{PM}_{\mathrm{V}}, \mathrm{PD}_{\mathrm{I}}, \mathrm{PD}_{\mathrm{II}}, \mathrm{PD}_{\mathrm{III}}, \mathrm{PD}_{\mathrm{IV}}$ and $\mathrm{PD}_{\mathrm{V}}$, where $\mathrm{P}$ is the index of sunflower oil, $\mathrm{M}$ - aminolysis of palm oil carried out in the presence of MEA, D - aminolysis of palm oil carried out in the presence of DEA, I- $\mathrm{Na}^{+}$, II$\mathrm{K}^{+}$, III- $\mathrm{NH}_{4}^{+}$, IV- MEA ${ }^{+}, \mathrm{V}-\mathrm{DEA}^{+}$. Basic physicochemical properties of intermediate and end-products of the reaction, as well as the compound and structure as set forth by IRspectroscopy have been presented in [12].

Surface activity of obtained salts has been analyzed on water-kerosene interface by stalagmometric method in the work. As is known, the interfacial tension at this phase boundary in the absence of surfactants at 22$24^{\circ} \mathrm{C}$ amounts to $46.0-46.5 \mathrm{mN} / \mathrm{m}$. Note that obtained data on surface activity of salts at $22^{\circ} \mathrm{C}$ are presented in Table 1 . Interfacial tension in the presence of $\mathrm{PD}_{\text {II }}$ on the basis of $\mathrm{K}^{+}$-salts of sulphate-derivatives of higher carboxylic acids synthesized on the basis of palm oil and DEA at 0.175 wt. \% concentration leads to the reduction of interfacial tension on water-kerosene interface down to $1.60 \mathrm{mN} / \mathrm{m}$ which evinces maximum surface activity among salts previously synthesized in the concentration of $0.005-0.2$ wt. \%.

As a result of stalagmometric measurements, isotherms of interfacial tension have been formed (Fig. 1 and 2.) where the dependence of interfacial tension on waterkerosene interface in the surfactant concentration is given by coordinates $\sigma-\ln C$. As is seen from the graph, interfacial tension decreases in the initial section with rise in salt concentration. That follows from adsorption process of surfactants at phase boundary and subsequent drop in the difference between polar liquid phases due to their confusion. The transition point to the horizontal portion of the isotherm corresponds to the critical micelle concentration. Research results reaffirm a fairly high surface activity of the salts.

According to the well-known theoretical formulas, some basic parameters of surfactants have been calculated on the basis of the data obtained and some thermo-dynamical parameters of micelle formation and adsorption processes. Calculated values of colloid-chemical parameters of the anionic surface active salts are presented in Table 2 where $\mathrm{C}_{\mathrm{CMC}}$ - critical micelle concentration, $\sigma_{\mathrm{CMC}}$ - interfacial tension of the solution at CMC, $\pi_{\mathrm{CMC}}$ - surface pressure, $\Gamma \mathrm{m}$ maximum adsorption, $\mathrm{A}_{0}$ - minimum crosssectional area of polar group, $d$ - average length of the molecule, $\Delta G_{\text {mic. }}$ - standard free energy of micelle - $\Delta G_{a d s}$ free energy of adsorption. 


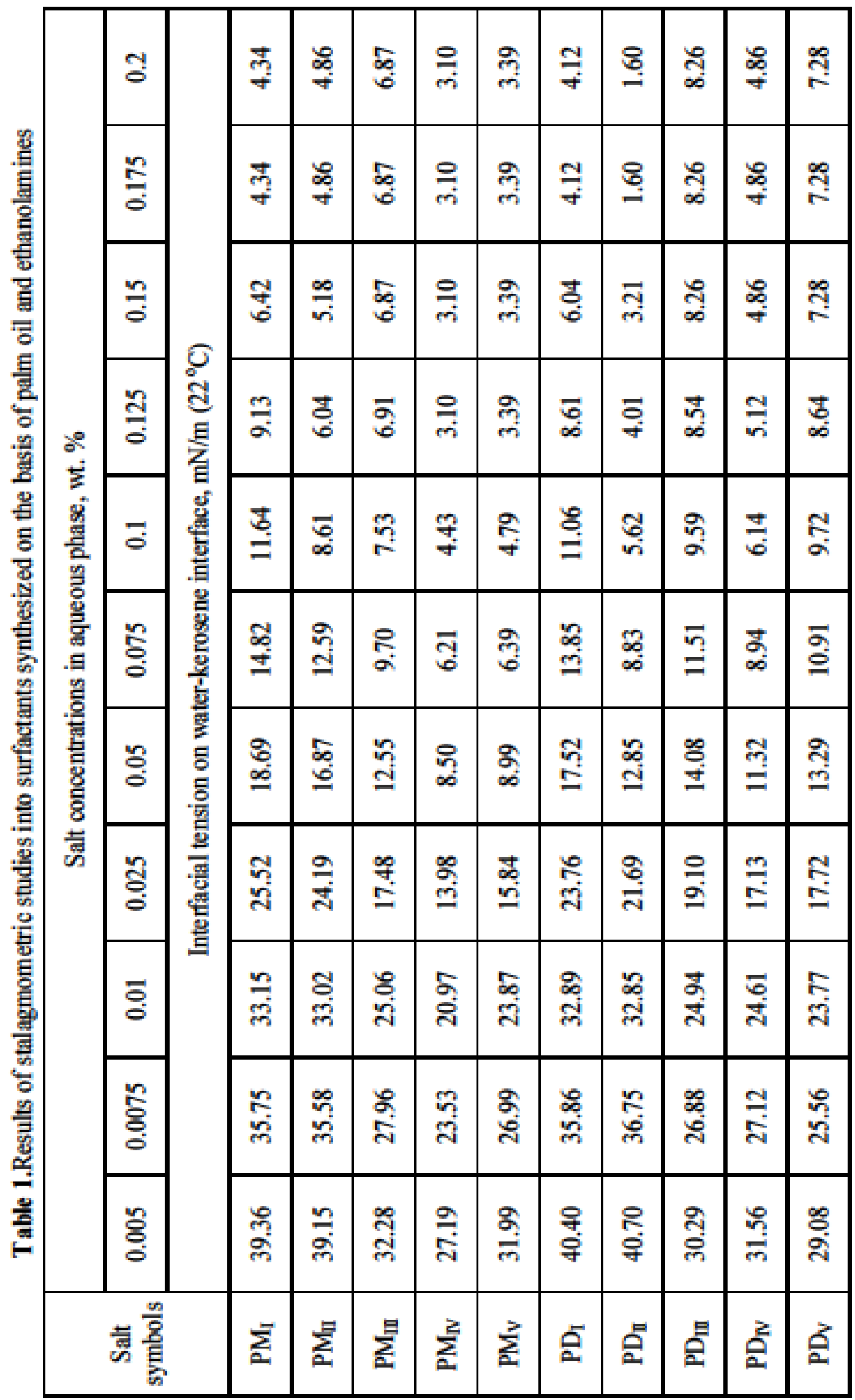




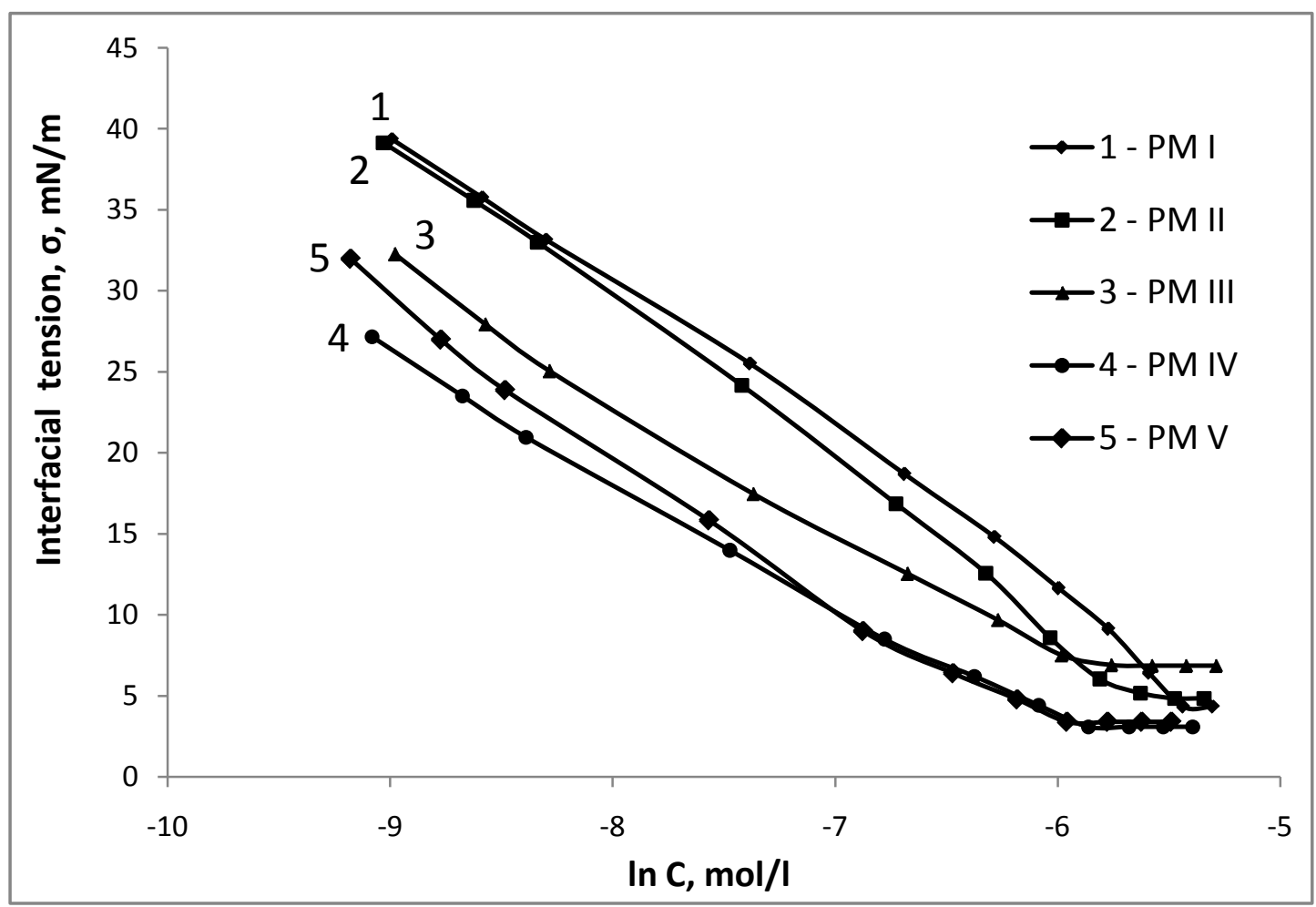

Fig. 1. Isotherms of interfacial tensions of surfactants synthesized on the basis of palm oil and monoethanolamine

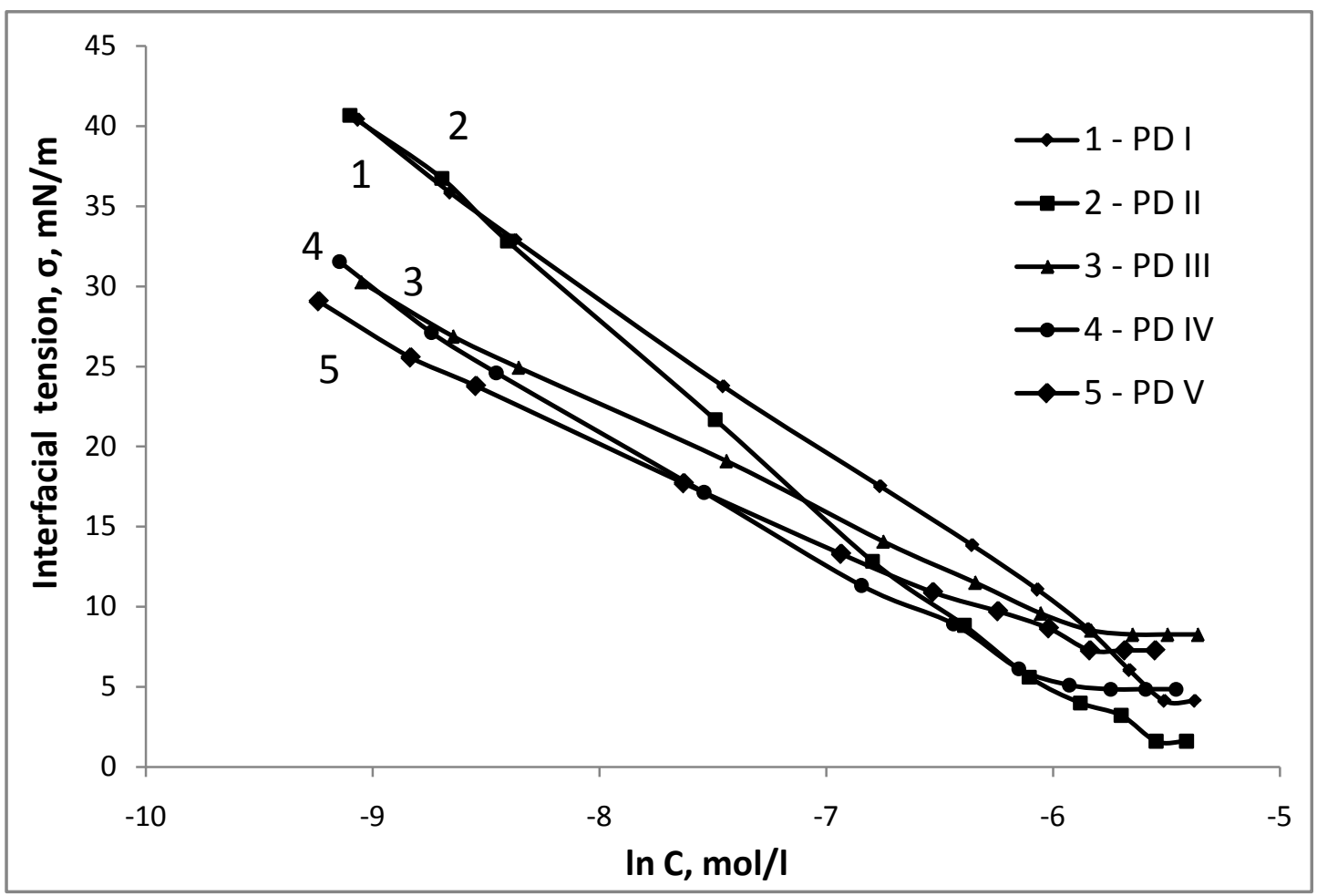

Fig. 2. Isotherms of interfacial tensions of surfactants, synthesized on the basis of palm oil and diethanolamine 


\begin{tabular}{|c|c|c|c|c|c|c|c|c|c|c|}
\hline$\xi^{3}$ & 7 & 8 & 8 & 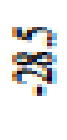 & 8 & $\frac{9}{4}$ & 8 & $\frac{9}{8}$ & $\$$ & $\frac{1}{3}$ \\
\hline $8^{-\frac{2}{3}}$ & 7 & $\frac{7}{7}$ & $\frac{\pi}{7}$ & प्ञ & $\frac{0}{7}$ & $\frac{\pi}{7}$ & $\frac{1}{7}$ & $\frac{9}{7}$ & च & $\frac{\pi}{7}$ \\
\hline 口 & 8 & $\geqslant$ & 8 & 8 & 于 & f & $\mathbb{E}$ & $\cong$ & $\vec{\Rightarrow}$ & 들 \\
\hline 解 & $\infty$ & 8 & 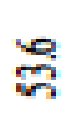 & 은 & 8 & 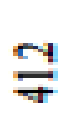 & 8 & $\frac{\infty}{0}$ & $\frac{3}{3}$ & 8 \\
\hline${ }_{0}^{\circ} \frac{1}{p}$ & $\mathbb{R}$ & $\frac{\mathrm{c}}{7}$ & 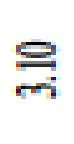 & $\stackrel{D}{E}$ & 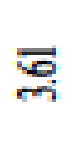 & 8 & 8 & 8 & $\mathbb{S}$ & 8 \\
\hline $0 \frac{E}{E}$ & 品 & $\equiv$ & 8 & $\frac{9}{1}$ & $\infty$ & 8 & $\nexists$ & 8 & 是 & E \\
\hline 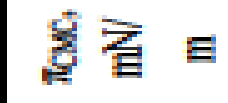 & $\frac{8}{7}$ & 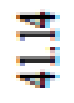 & 梠 & 9 & 9 & $\frac{6}{7}$ & च & $\frac{t^{2}}{m}$ & 士 & E \\
\hline 8 글 & $\underset{7}{7}$ & 8 & $\infty$ & $\Rightarrow$ & 9 & $\frac{5}{4}$ & 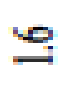 & 2 & 8 & 8 \\
\hline 约 & $\frac{7}{5}$ & क & $\frac{8}{8}$ & 8 & 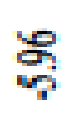 & $\vec{n}$ & 8 & is & $\frac{8}{8}$ & 8 \\
\hline$\frac{3}{3} \bar{E}$ & $\Rightarrow$ & $\frac{9}{7}$ & $\stackrel{R}{\pi}$ & $\$$ & $\approx$ & $\stackrel{9}{\square}$ & $\vec{a}$ & $\sqrt{n}$ & $g$ & 8 \\
\hline E & I & 9 & 8 & A & $\bar{B}$ & 吾 & 9 & 8 & $\mathrm{~g}$ & I \\
\hline 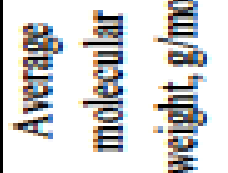 & 都 & $\frac{\infty}{7}$ & 5 & $\frac{8}{8}$ & D & $\frac{7}{8}$ & 尔 & $\mathrm{E}$ & 尽 & \pm \\
\hline $\begin{array}{l}\text { 홀 } \\
\text { 롤 }\end{array}$ & 竞 & 是 & 를 & i & iz & 동 & 号 & 是 & $\vec{B}$ & $\overrightarrow{1}$ \\
\hline
\end{tabular}




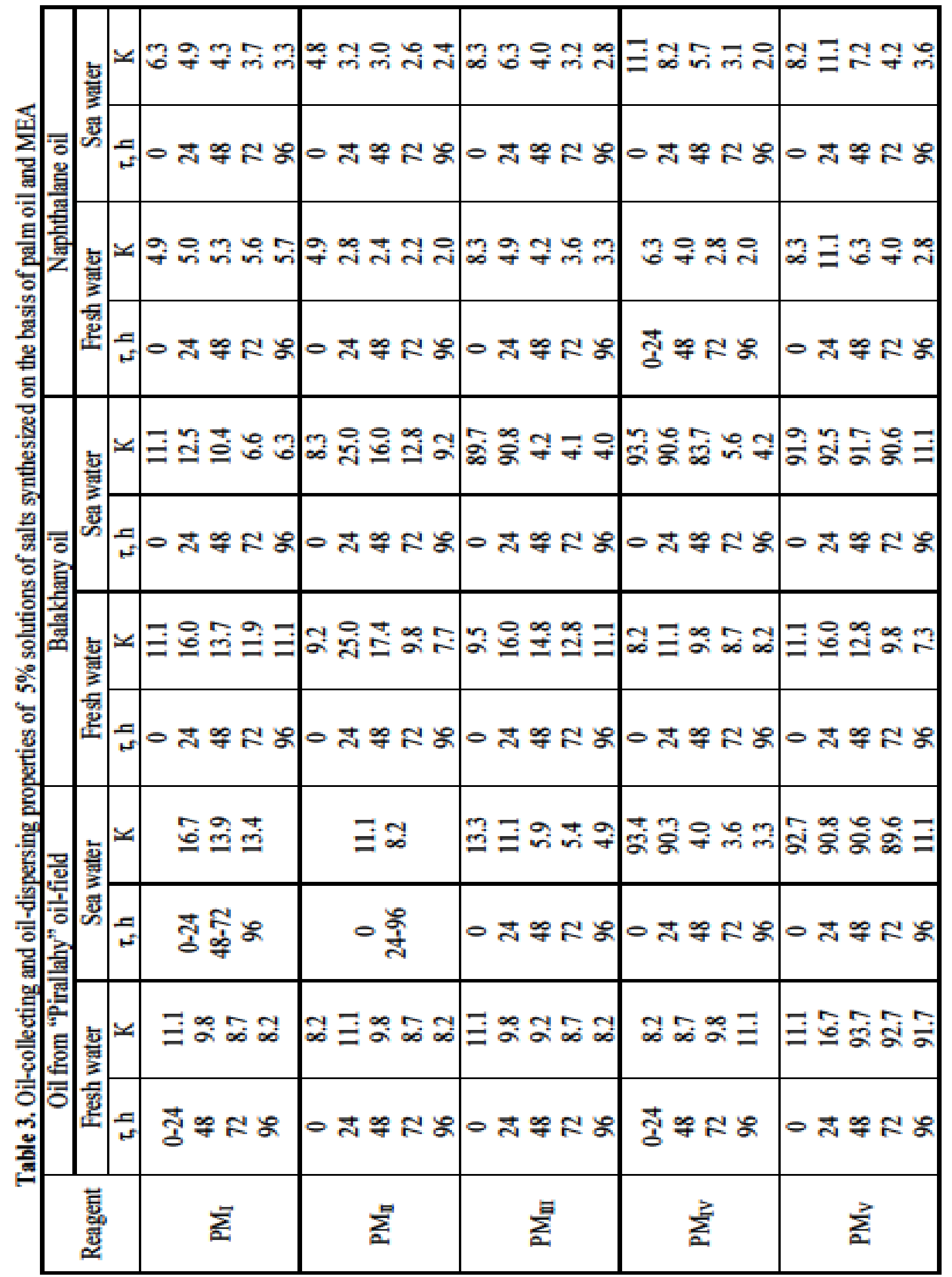




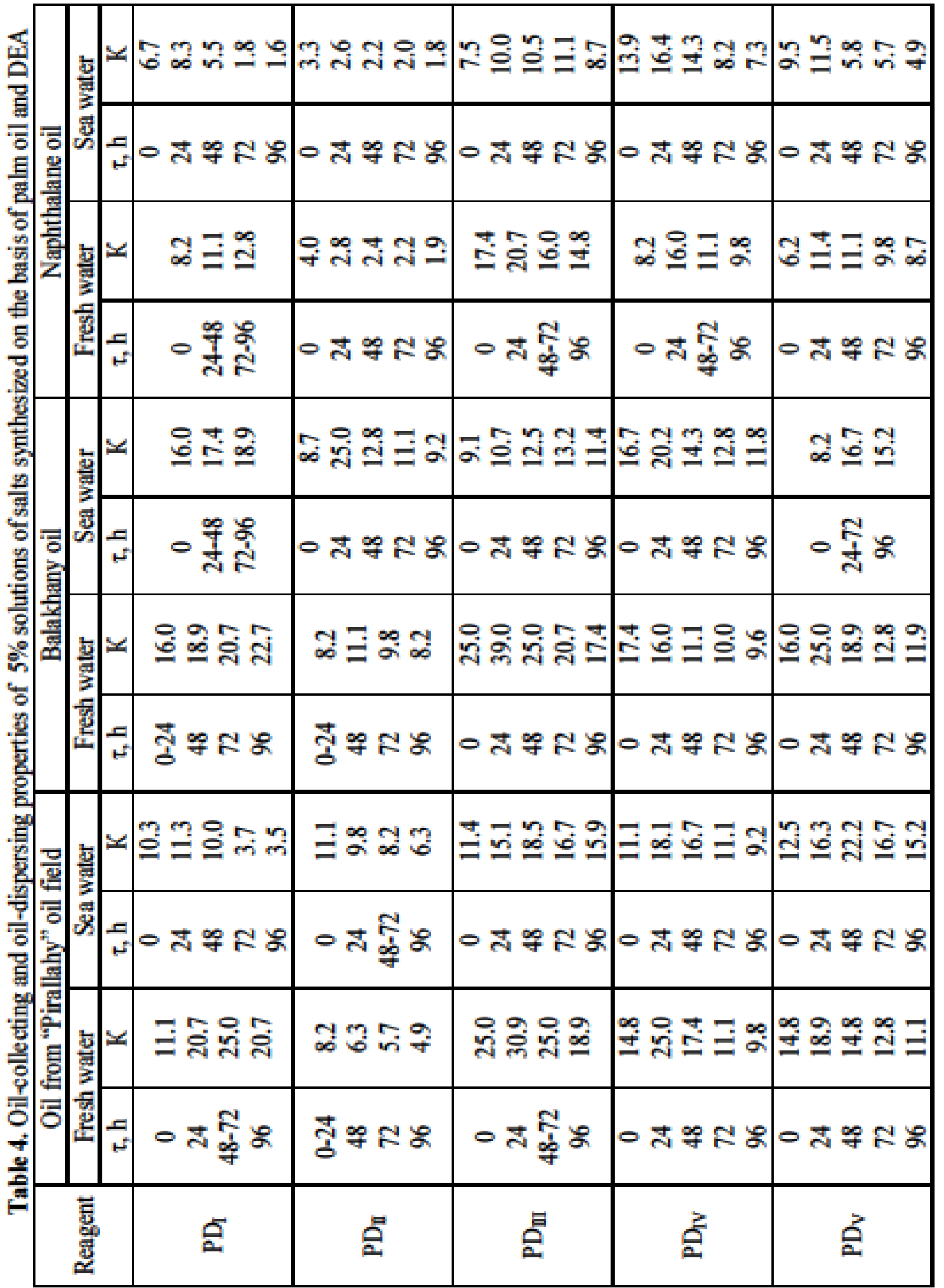


Of great interest is the analysis of oilcollecting and oil-dispersing properties of synthesized salts of thin oil film on the surface of fresh and sea water Laboratory tests went to show that synthesized salts of sulphatederivatives of higher carboxylic acids display higher activity as oil-collecting and oildispersing reagents on the surface of sea and fresh water (Table 3 and 4). $\mathrm{PD}_{\text {III }}\left(\mathrm{K}_{\text {max. }}=30.9\right.$, $\tau=24 \mathrm{~h}$ ) demonstrates maximum collecting effect of oil film from "Pirallahy" oil-field in fresh water through the use of $5 \%$ solutions of the reagents, true, in the sea water. $\mathrm{PD}_{\mathrm{V}}$ $\left(\mathrm{K}_{\text {max. }}=22.2, \tau=48 \mathrm{~h}\right)$.

Among the reagents of mixed-type effect, dispersion is replaced by collecting which is observed in $\mathrm{PM}_{\mathrm{IV}}\left(\mathrm{K}_{\mathrm{d}}=93.4 \%, \tau=0 \mathrm{~h} ; \mathrm{K}_{\mathrm{d}}=\right.$ $90.3 \%, \tau=24 \mathrm{~h} ; \mathrm{K}=4.0, \tau=48 \mathrm{~h} ; \mathrm{K}=3.6, \tau=$ $72 \mathrm{~h} ; \mathrm{K}=3.3, \tau=96 \mathrm{~h})$ and $\mathrm{PM}_{\mathrm{V}}\left(\mathrm{K}_{\mathrm{d}}=92.7 \%, \tau\right.$ $=0 \mathrm{~h} ; \mathrm{K}_{\mathrm{d}}=90.8 \%, \tau=24 \mathrm{~h} ; \mathrm{K}_{\mathrm{d}}=90.6 \%, \tau=48$ $\mathrm{h} ; \mathrm{K}_{\mathrm{d}}=89.6 \%, \tau=72$ hours; $\mathrm{K}=11.1, \tau=96 \mathrm{~h}$ ) in the sea water medium as well as mixed-type collecting effect which is replaced by dispersion at $\mathrm{PM}_{\mathrm{V}}\left(\mathrm{K}=11.1, \tau=0 \mathrm{~h} ; \mathrm{K}=16.7, \tau=24 \mathrm{~h} ; \mathrm{K}_{\mathrm{d}}\right.$ $=93.7 \%, \tau=48 \mathrm{~h} ; \mathrm{K}_{\mathrm{d}}=92.7 \%, \tau=72 \mathrm{~h} ; \mathrm{K}_{\mathrm{d}}=$ $91.7 \% \tau=96 \mathrm{~h}$ ) in the fresh water medium.

$\mathrm{PD}_{\text {III }}$ reagent $\left(\mathrm{K}_{\text {max. }}=39.0, \tau=24 \mathrm{~h}\right)$ is also an effective collector of Balakhany oil film in the fresh water medium. It should be noted that in the sea water medium maximum multiplicity of collection presents $\mathrm{PM}_{\mathrm{II}}\left(\mathrm{K}_{\max .}=\right.$ $25.0, \tau=24 \mathrm{~h})$ and $\mathrm{PD}_{\mathrm{II}}\left(\mathrm{K}_{\mathrm{max} .}=25.0, \tau=24 \mathrm{~h}\right)$ reagents. Three reagents are synthesized on the basis of monoethanolamine - $\mathrm{PM}_{\mathrm{III}}\left(\mathrm{K}_{\mathrm{d}}=89.7 \%\right.$, $\tau=0 \mathrm{~h} ; \mathrm{K}_{\mathrm{d}}=90.8 \%, \tau=24 \mathrm{~h} ; \mathrm{K}=4.2, \tau=48 \mathrm{~h}$; $\mathrm{K}=4.1, \tau=72 \mathrm{~h} ; \mathrm{K}=4.0, \tau=96 \mathrm{~h}), \mathrm{PM}_{\mathrm{IV}}\left(\mathrm{K}_{\mathrm{d}}=\right.$ 93.5\%, $\tau=0 \mathrm{~h} ; \mathrm{K}_{\mathrm{d}}=90.6 \%, \tau=24 \mathrm{~h} ; \mathrm{Kd}=$ 93,7\%, $\tau=48$ h; $\mathrm{K}=5,6, \tau=72 \mathrm{~h} ; \mathrm{K}=4.2, \tau=$ $96 \mathrm{~h})$ and $\mathrm{PM}_{\mathrm{V}}\left(\mathrm{K}_{\mathrm{d}}=91.2 \%, \tau=0 \mathrm{~h} ; \mathrm{K}_{\mathrm{d}}=\right.$ $92.5 \%, \tau=24 \mathrm{~h} ; \mathrm{K}_{\mathrm{d}}=91.7 \%, \tau=48 \mathrm{~h} ; \mathrm{K}_{\mathrm{d}}=$ $90.6 \%, \tau=72 \mathrm{~h} ; \mathrm{K}=11.1, \tau=96 \mathrm{~h}$ ) firstly by dispersion which is followed by collecting of Balakhany oil film show mixed-type effects.

All of the reagents synthesized on the basis of palm oil have no dispersibility on Naphthalane oil both in fresh and sea water. Maximum multicipility of collecting oil film is observed at $\mathrm{PD}_{\text {III }}$ reagents $\left(\mathrm{K}_{\max }=20.7, \tau=24 \mathrm{~h}\right)$ in the fresh water medium and $\mathrm{PD}_{\mathrm{IV}}\left(\mathrm{K}_{\text {max. }}=\right.$ $16.4, \tau=24 \mathrm{~h}$ ) in the sea water medium.

Following the analysis results, one can conclude that, in the main, all of the reagents display sufficient high oil-collecting and oildispersing activity in removing off thin oil film from sea and fresh water surfaces. In some cases, a mixed-type effect is observed collecting is replaced by dispersing and vice versa.

\section{References}

1. Lange K.R. Surfactants. St.-Petersburg: "Professiya” Publ. 2005, 239 p.

2. Drew Myers. Surfactant science and technology. Hoboken, New Jersey: John Wiley and Sons. Inc., 2006, 380 p.

3. Elewady G.Y., El-Said I. A., Fouda A.S., Anion Surfactants as Corrosion Inhibitors for Aluminum Dissolution in $\mathrm{HCl}$ Solutions. Int. J. Electrochem. Sci., 2008, vol. 3, pp. 177-190.

4. Ramesh S., Rajeswari S. Evaluation of inhibitors and biocide on the corrosion control of copper in neutral aqueous environment. Corrosion science. 2005, vol.47, p.151-169.

5. Abbasov V.M., Aliyeva L.I., Samedov A.M., Ismayilov I.A., Abdullayev E.Sh.
Experience and perspectives for formation and use of multifunctional reagents in oil industry. Proceedings of IPCP of ANAS. Baku: Elm Publ. 2009, pp. 133-152.

6. N. El Mehbad. Development of multifunctional additives for high quality Lube oil. Journal of Power and Energy Engineering. 2013, vol.1, pp.84-89.

7. Djedri S., Issaadi R., D. Le Cerf, L. Picton, N. Moulai-Mostefa Surfactants synthesis using petroleum fractions and crude oil : application in microemulsion formulation. Journal of Dispersion Science and Technology. 2010, vol. 31, p.877-882.

8. Di Zhang, Pengyuan Zhang, Haikui Zou, Guangwen Chu, Wei Wu, Zhongwu Zhu, 
Lei Shao, Jianfeng Chen . Synthesis of Petroleum Sulfonate Surfactant by Different Sulfonating Agent with Application of HIGEE Technology. Chinese Journal of Chemical Engineering. 2010, vol.18, pp. 848-855.

9. Kharchenko U.V., Makarenko N.V., Safronov P.P., Karabtsov A.A., Kovekhova A.V., Zemnukhova L.A. Protective effect of the wastes from recycling of vegetable raw materials on steel corrosion in aggressive mediums. Zhurnal Prikladnoi Khimii -The Russian Journal Of Applied Chemistry. 2008, vol. 81, № 9. p. 1484-1489.

10. Abbasov V.M., Ismayilov I.T., Hany M. Abd El-Lateef, Akhmadbeyova S.F., Anticorrosive activities of some novel surfactants based on vegetable oils. European chemical Bulletin, 2014, 3(5), pp. 437-440.
11. Ismayilov I.T., Abbasov V.M., Hany M. Abd El-Lateef, Mamedkhanova S.A. Yolchuyeva U.C., Salmanova Ch.K. Carbon dioxide corrosion inhibition of carbon steel by using some surfactants based on sunflower oil and monoethanolamine. Elixir international journal (Corrosion). 2013, vol. 65, p. 19830-19835.

12. Ismayilov I.T. Anticorrosive reagents of complex action on the basis of the salts of sulphate-derivative higher carbonic acids, derived from palm oil. Processes of petrochemistry and oil refining, 2015, vol. 16, № 3 (63), pp. 183-198. (In Azerbaijan).

13. Chu Z., Feng Y. Vegetable-Derived LongChain Surfactants Synthesized via a "Green" Route ACS Sustainable Chem. Eng. 2013, vol. 1, pp.75-79.

\title{
СИНТЕЗ И ИССЛЕДОВАНИЕ КОЛЛОИДНО-ХИМИЧЕСКИХ СВОЙСТВ ПАВ НА ОСНОВЕ ПАЛЬМОВОГО МАСЛА И ЭТАНОЛАМИНОВ
}

\author{
И.Т.Исмаилов \\ Институт нефтехимических проиессов им. Ю.Г.Мамедалиева \\ Национальной АН Азербайджана, \\ А31025, пр. Ходжальь, 30, г.Баку, Азербайджан \\ Химический факультет МГУ им. М.В. Ломоносова, \\ 119991, Ленинские горы, д. 1, стр. 3, г.Москва, Россия \\ e-mail: ismayil999@gmail.com
}

\begin{abstract}
Синтезированы анионные поверхностно-активные $\mathrm{Na}^{+}, \mathrm{K}^{+}, \mathrm{NH}_{4}^{+},-\mathrm{NH}_{2}{ }^{+}-\mathrm{CH}_{2}-\mathrm{CH}_{2}-\mathrm{OH} u$ $\mathrm{NH}^{+}-\left(\mathrm{CH}_{2}-\mathrm{CH}_{2}-\mathrm{OH}\right)_{2}$ соли сульфатпроизводных высиих карбоновых кислот. Сульфатпроизводные получены взаимодействием пальмового масла с этаноламинами (моноэтаноламин и диэтаноламин) при мольном соотношении равным 1:2 с последующим модифицированием серной кислотой продуктов реакции. Определены основные коллоиднохимические параметры синтезированных солей и исследована их нефтесобирающая $u$ нефтедиспергируюшая способность на поверхности вод с различной степенью минерализачии.
\end{abstract}

Ключевые слова: пальмовое масло, этаноламины, поверхностное натяжение, критическая концентрация мицеллообразования, свободная энергия адсорбции.

Поступила в редакиฺию 21.03.2017. 


\section{PALMA YAĞI VO ETANOLAMINLOR OSASINDA SAM-ların SINTEZI VO KOLLOID-KIMYOVI XASSOLORINİN ÖYRONILMOSI}

\section{I.T.İsmayulov}

AMEA Y.Mammadaliyev adina Neft-Kimya Proseslari Institutu

Az 1025 Bakl, Xocall prospekti, 30

M.Lomonosov adına Moskva Dövlat Universitetinin kimya fakultəsi

119991, Leninskiye qorl, ev. 1

e-mail: ismayil999@gmail.com

Ali karbon turşularının sulfat töramalarinin anion sathi aktiv $\mathrm{Na}^{+}, \mathrm{K}^{+}, \mathrm{NH}_{4}{ }^{+},-\mathrm{NH}_{2}{ }^{+}-\mathrm{CH}_{2}-\mathrm{CH}_{2}-\mathrm{OH}$ və $-\mathrm{NH}^{+}-\left(\mathrm{CH}_{2}-\mathrm{CH}_{2}-\mathrm{OH}\right)_{2}$ duzlarl sintez olunmuşdur. Sulfat törəmələr, palma yağının etanolaminlarla (monoetanolamin vo dietanolamin) 1:2 mol nisbotindo qarşılıqlı təsir reaksiya mahsullarının sulfat turşusu ilo modifikasiyası ila alınmışdır. Sintez olunmuş duzların osas kolloidkimyəvi parametrləri tayin olunmuş, farqli minerallıqlı suların səthində neftylğıcılıq və neftdisperslamə qabiliyyatlari öyrənilmişdir.

Açar sözlər: palma yă̆l, etanolaminlər, səthi garginlik, kritik misella əməlagətirmə qatılı̆̆l, adsorbsiya enerjisi

Redaksiyaya daxil olub 28.03.2017. 